\title{
NEW SCHOLARSHIP
}

\section{Narrative and Meaning in Early Modern England} Browne's Skull and Other Histories Howard Marchitello

This study of narrative techniques in Renaissance discourse analyzes imaginative conjunctions of literary texts, such as those by Shakespeare and Thomas Browne, with developments in scientific and technical writing.

Cambridge Studies in Renaissance

Literature and Culture 20

0-521-58025-0 Hardback \$59.95

\section{English Merchants in}

\section{Seventeenth-Century Italy} Gigliola Pagano de Divitiis

This book shows how England's conquest of Mediterranean trade proved to be the first step in building her future economic and commercial hegemony, and how Italy lay at the heart of that process.

Cambridge Studies in Italian History and Culture

0-521-58031-5 Hardback $\$ 59.95$

\section{British Literary Culture and Publishing Practice, 1880-1914}

\section{Peter D. McDonald}

This book is about the radical transformation of British literary culture during the period 1880 to 1914 as seen through the early publishing careers of Joseph Conrad, Arnold Bennett and Arthur Conan Doyle. McDonald examines the cultural politics of the period by considering the social structure of the literary world in which these writers worked.

Cambridge Studies in Publishing and Printing History

0-521-57149-9 Hardback \$59.95
Classical Culture and the Idea of Rome in Eighteenth-Century England

\section{Philip Ayres}

In the century following the Revolution of 1688, the ruling class promoted - by way of its patronagea classical frame of mind embracing all the arts, on the foundations of "liberty" and "civic virtue". Ayres' study shows that the propensity to adopt the self image of virtuous Romans was the attempt of a newly empowered oligarchy to dignify and vindicate itself by association with an idealized image of Republican Rome.

0-521-58490-6 Hardback $\$ 54.95$

\section{Remaking Queen Victoria \\ Margaret Homans and Adrienne Munich, Editors}

This collection of essays by noted scholars in literature, cultural studies, art history, and women's studies explores the diverse and sometimes conflicting meanings this complex and fascinating figure held for her subjects around the world and even for those outside her empire.

Contributors: Margaret Homans, Adrienne Munich, Elizabeth Langland, Mary Loeffelholz, Alison Booth, Nicola J. Watson, Sharon Aronofsky Weltman, Maria Jerinic, Robin Bott, Gail Turley Houston, Susan P. Casteras, Karen Chase, Michael Levenson, Dagni Bredesen, Janet Winston

Cambridge Studies in Nineteenth-Century Literature and Culture 10

0-521-57379-3 Hardback \$59.95

0-521-57485-4 Paperback \$19.95 


\section{FROM CAMBRIDGE}

\section{War and British Society, 1688-1815}

\section{H.V. Bowen}

The author shows that between 1688 and 1815 war touched all aspects of life in Britain, transforming a wide range of economic and social institutions, processes and structures. This book will be essential reading for all students of eighteenth-century British history, society and culture.

New Studies in Economic and Social History 0-521-57226-6 Hardback \$39.95 0-521-57645-8 Paperback $\$ 11.95$

\section{Gregory the Great and his World \\ R.A. Markus}

The book is a study of Gregory the Great, the pope who sent Augustine (of Canterbury) and his fellow missionaries to convert the heathen English to Christianity (597). Markus gives a full account of Gregory's life and work, his thought and spirituality, within the setting of the world at the end of the sixth century.

0-521-58430-2 Hardback \$59.95

0-521-58608-9 Paperback $\$ 22.95$

\section{Beardsley, Japonisme, and the Perversion of the Victorian Ideal \\ Linda Gertner Zatlin}

Placing Japanese woodblock prints in the English and French cultural milieu of the last third of the Victorian era, Zatlin examines Beardsley's technical and thematic adaptations of Japanese art. She shows how Japanese art set Beardsley free from British artistic restraints and enabled him to create his striking and personal style.

0-521-58164-8 Hardback $\$ 70.00$
The Cambridge Companion to Samuel Johnson Greg Clingham, Editor

This Companion provides a unique introduction and guide to the works and life of one of the key figures in English literary history.

Contributors: Philip Davis, Catherine N. Parke, Howard D. Weinbrot, Paul J. Korshin, Eithne Henson, Robert De Maria Jr, Robert Folkenflik, Clement Hawes, Fred Parker, Philip Smallwood, Greg Clingham, Michael Suarez, John Wiltshire, Tom Keymer, Steven Lynn

Cambridge Companions to Literature 0-521-55411-X Hardback \$59.95 0-521-55625-2 Paperback \$18.95

\section{Deadly Dreams}

Opium and the Arrow War (1856-1860) in China

\section{J.Y. Wong}

Many have accepted that the Arrow War (1856-60) was caused by an insult to the British flag belonging to the pirate boat. Wong argues that Britain's reliance on the opium trade with China played a far greater role in pushing the diplomatic conflict into war and offers penetrating insights into theories of imperialism and how they might be reassessed.

Cambridge Studies in Chinese History, Literature and Institutions

0-521-55255-9 Hardback \$69.95

Available in bookstores or from

AMBRIDGE

UNIVERSITY PRESS

40 West 20th Street

New York, NY 10011-4211

Call toll-free $\mathbf{8 0 0 - 8 7 2 - 7 4 2 3 . ~}$

Web site: http://www.cup.org

MasterCard/VISA accepted.

Prices subject to change. 


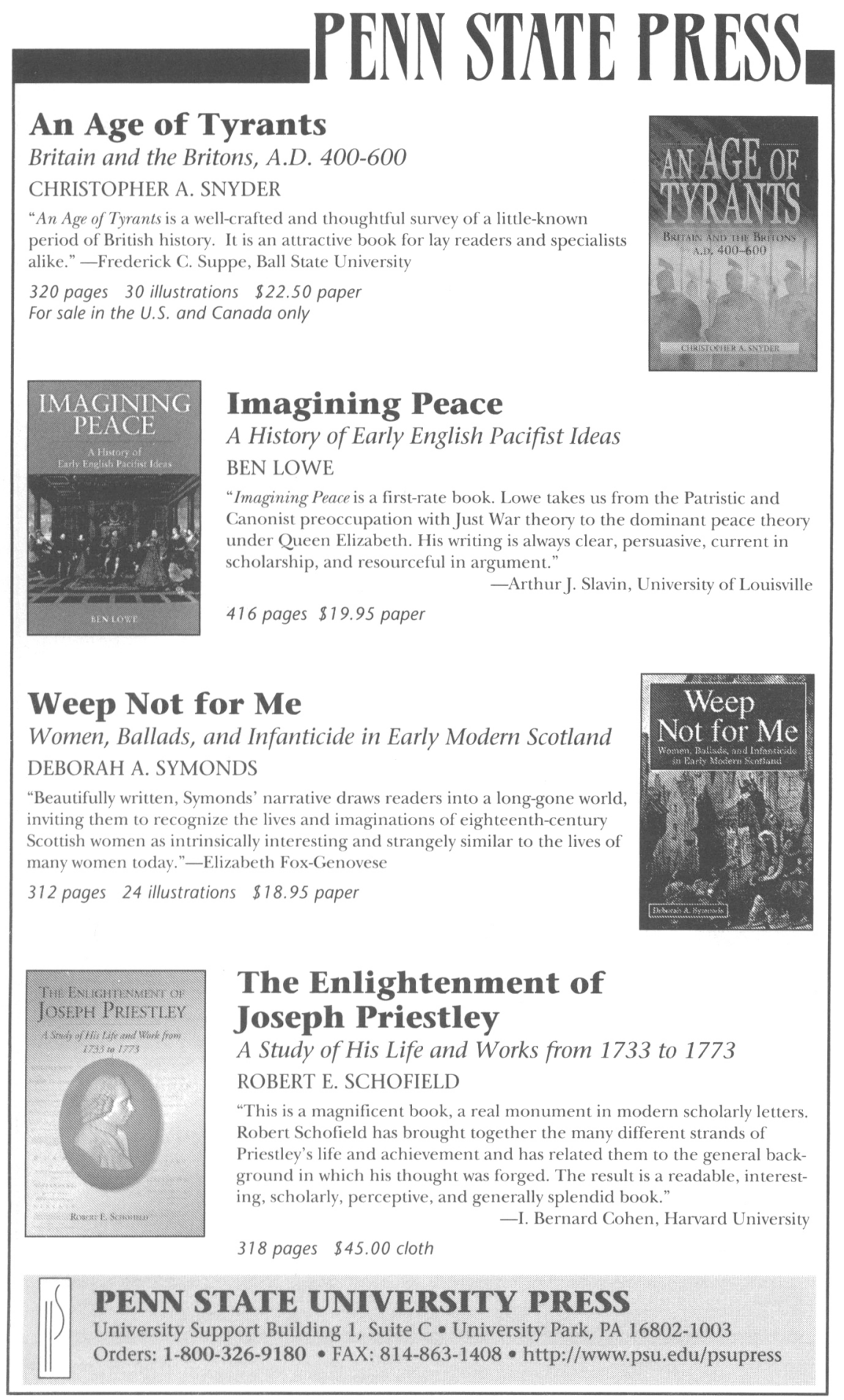




\section{Selected Articles}

Envisioning Lastness:

Byron's Darkness,

Campbell's The Last Man, and the Critical Aftermath

(Morton Paley)

Tyranny and Translation:

Shelley's Unbinding of

Prometheus

(Jennifer Wallace)

Keats' Belle Dame and the

Sexual Politics of Leigh

Hunt's Indicator

(John Barnard)

Pit-Bull Poetics: One Battle in Byron's 'War in Words'

(Jane Stabler)

Between Flippancy and

Terror: Shelley's Marianne's

Dream

(Tim Clark and Mark Allen)

Revolution, Revenge, and

Romantic Tragedy

(John Kerrigan)

- Please enter my subscription to

Romanticism

ISSN 1354-991X

Volume 4, 1998

2 issues per year

\section{Individuals}

$\square$ UK and EC $£ 21.00$

N. America $\$ 42.50$

Rest of World $£ 23.00$

\section{Institutions}

UK and EC $£ 42.00$

․ America $\$ 85.00$

口 Rest of World $£ 46.00$

- Please send me a free sample copy

Back Issues

$£ 16.00 / \$ 29.50$ each
The journal of Romantic culture and criticism Romanticism

ISSN 1354-991X

Volume 4, 1998 - 2 issues per year

Editors

JDrummond Bone - Nicholas Roe - Timotby Webb

The only major international scholarly publication

of its kind edited and published in Britain, Romanticism offers a much-needed forum for the flourishing diversity of Romantic studies today. Focusing on the period $1750-1850$, it publishes critical, historical, textual and bibliographical essays prepared to the highest scholarly standards, reflecting the full range of current methodological and theoretical debate. With an extensive book review section, Romanticism constitutes a vital arena for scholarly debate in this liveliest field of literary studies.

\section{Order Form}

Pleose retum to the address below

Surface postage is included in the subscription.

Please add $65 / \$ 10$ for airmail delivery.

Name

Address

Edinburgh University Press, 22 George Square, Edinburgh, EH8 9LF Tel: $+44(0)$ |3| 6506207 Fax: $+44(0) 1316620053$ http://www eup.ed.ac.uk/ 


\section{Selected Letters of Robert Louis Stevenson}

Edited by Ernest Mehew

"This selection...shows [Stevenson's] brilliance sparkling on every page....The book is wonderfully abundant....An exhilarating read."-The Observer (UK) $\$ 39.95$

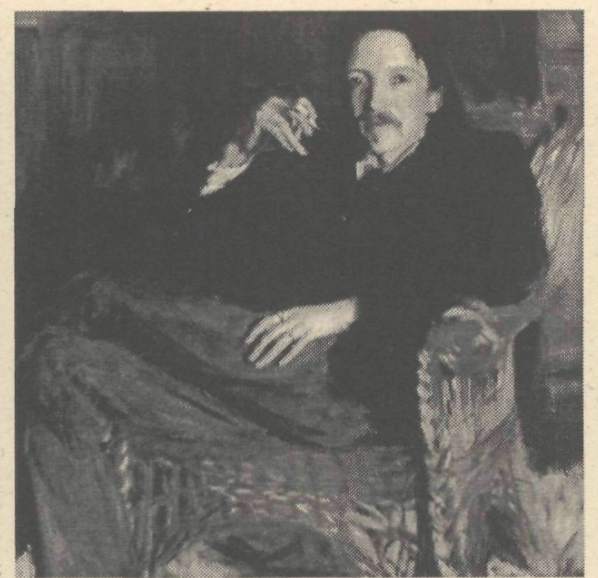

John Singer Sargent, portrait of Rohert Louis Stevenson at Bournemouth (detail), 1887. (Taft Museum, Cincinnati)

\section{Wilde the Irishman}

Edited by Jerusha McCormack

In this vigorous study, leading Irish literary and artistic figures -including Nobel laureate Seamus Heaney-, examine the surprisingly neglected theme of the "Irishness"' of Oscar Wilde. The book includes critical essays that explore how Wilde reflected the Irish tradition as well as creative responses to Wilde by poets, playwrights, sculptors, a short story writer, and an actor. 28 illus. $\$ 30.00$

\section{The British Monarchy and the French Revolution}

Marilyn Morris

"Morris engages directly and intelligently with other historians in the field. She makes a significant contribution to the history of English monarchy."

-Paul Monod

10 illus. $\$ 28.50$
New in Paper

\section{Thomas Cranmer}

\section{A Life}

Diarmaid MacCulloch

"This lucidly wriften, deeply researched and surprisingly accessible biography of the man who served Henry VIII as Archbishop of Canterbury...ably explores both Cranmer's drive and his persistent doubts."-Allen D. Boyer, New York Times Book Review

Winner of the 1996 Whitbread Biography Award Winner of the 1996 James Tait Black Memorial Prize for Biography

Winner of the 1996 Duff Cooper Prize 40 illus. $\$ 18,00$ paperbound

\section{New in Cloth and Paper}

\section{Edward IV}

\section{Charles Ross}

with a new foreword by Ralph A. Griffiths

"A rare combination of scholarship and shrewd common sense."

-John Raymond, Sunday Times.

Yale English Monarchs Series

37 illus. $\$ 40.00$ cloth; $\$ 18.00$ paperbound

\section{King John}

W.L. Warren

with a new foreword by D.A. Carpenter

"Perhaps the best general treatment of the life and reign of King John which has been published in England during the past forty years."

\section{- Times Literary Supplement}

Yale Englișh Monarchs Series

8 illus. $\$ 40.00$ cloth; $\$ 18.00$ paperbound 


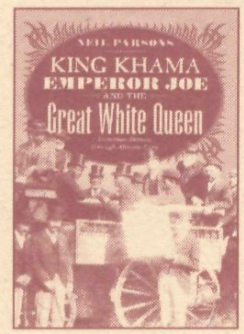

\section{King Khama, Emperor Joe, and the Great White Queen \\ Victorian Britain through African Eyes}

\section{Neil Parsons}

"In an account which frequently echoes those eighteenth-century satires on national characteristics, Neil Parsons has skilfully combined an extraordinary range of press reports and other archival materials to reconstruct day by day the uneasy encounter of two largely alien worlds. . . . For the light it throws on the prelude to the [Jameson] Raid, but above all for its portrayal of the awkwardness, naivety, range of prejudice and genuine sympathies experienced on all sides in the proces's of imperial exchange, this is a remarkable and unusual book." Andrew Porter, Times Literary Supplement

*Paper \$18.95

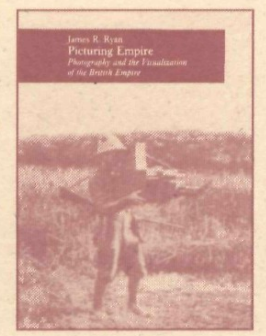

\section{Picturing Empire}

\section{Photography and the Visualization} of the British Empire

\section{James R. Ryan}

'In this fascinating study of the 'optics' of Empire, Ryan provides an extensive and engaging account of the British Empire as a photographic text. Metaphoric allusions to the spectacle of power or the 'eye' of authority are now translated into an illuminating survey of Empire as a photographic project, and photography as an imperial endeavour."-Homi K. Bhabha, University of Chicago

\section{Cloth $\$ 38.0088$ halftones}

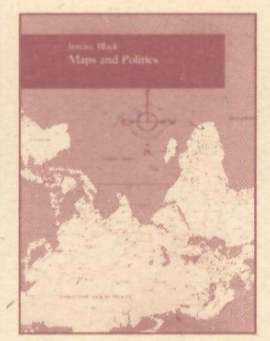

\section{Maps and Politics Jeremy Black}

In the lively and well-illustrated Maps and Politics, Jeremy Black argues persuasively that the supposed "objectivity" of the map-making and map-using process cannot be divorced from aspects of the politics of representation.

"Historian Jeremy Black's elegantly provocative critique of western cartography warrants the attention of anyone intrigued by the power and mystique of maps."-Mark Monmonier, author of How to Lie with Maps, Second Edition

Cloth $\$ 35.0010$ color plates, 50 halftones

*Cloth edition available

\section{The University of Chicago Press}

5801 South Ellis Avenue, Chicago, Illinois 60637 Visit us at http://www.press.uchicago.edu 